\title{
Cultivation Strategy on College Students' Socialist Core Values in Multicultural Perspective
}

\author{
Minghui Li \\ College of International Exchange, Bohai University, Jinzhou, 121013, China \\ liminghui0607@sina.cn
}

Keywords: multicultural perspective; college students; socialist core values; cultivation strategy

\begin{abstract}
Multicultural shock people's interests and ideas increasingly diversified, have a significant impact on college students' socialist core values. This research with diverse culture theory and the theory of socialist core values as the instruction, from the Angle of education management and education workers, solve the problem of cultivating college students' socialist core values of strategy. From the education pattern, the safeguard mechanism, methods, path optimization, the idea of education, social environment, the eight aspects, such as the mechanism of innovation way, put forward the feasible strategy. This study has enriched the college students' socialist core values education theory system, in the new era background, promoting college students' socialist core values education has important theoretical and realistic significance.
\end{abstract}

\section{Introduction}

Socialist core values is the kernel of the system of socialist core values, reflect the radical nature of the socialist core value system and the basic characteristics, reflects the rich connotation of the socialist core value system and practical requirements, is the height of the socialist core value system of concise and concentrated expression. Since the eighteenth national congress of the communist party of China, attaches great importance to cultivate and practice the socialist core values. Around the cultivation of the political bureau of the central committee and carry forward the socialist core values, to carry forward the Chinese traditional virtue for collective learning. The CPC central committee attaches great importance to and strongly deployment, in order to strengthen the socialist core values education practice pointed out the direction, provides important follow. College students is the core of the youth, are the backbone of the country in the future construction and development, is the builders and successors to the cause of socialism in our country. The values of college students affects not only the mainstream values of our society in the future, and decided the future of our country's future and destiny. Therefore, the socialist core value system and the socialist core values into the ideological and political education, with the socialist core value system and the socialist core values to cultivate college students to become qualified builders and successors of the socialist cause in China, is an important task of cultivating socialist new.

Many countries and regions are fully realized in the native culture under the background of diversified development, the core values in the importance of enhancing cultural soft power strategy. Helps to form the core values of minds and value identity, maintaining the social stability, is conducive to eliminate the gap between different nationalities, races, realize mutual communion, shaping the stable social relations and foreign national image as a whole. Cultivation of contemporary college students' socialist core values as an eternal topic of higher education in our country, is the core issue of college students' ideological and political education work. College students are the hope of the nation and the future of our motherland, their development is about the development of the society, their value orientation about the future of society as a whole, the level of their core values, is directly related to the degree of social spiritual civilization construction in our country in the future. Thus, strategy research is the socialist core values are the primary problems in cultivating the college students. Therefore, pay attention to cultivate college students' socialist core values, the unity of theory and practice of promoting the integration and optimization of cultivation strategies, should be the socialist core values of contemporary college students 
cultivate the prominent problems to be solved. At the same time, pay attention to and strengthen the socialist core values in the young students cultivation strategy research, and promote the group firm ideal faith in the realization of the "China dream" era.

\section{Research Significance}

Socialist core values as the mainstream values of social ideological trend, to people form the correct values, make reasonable value judgment, guiding the behavior of real activity plays an important role. Colleges and universities as an important area, combines the variety of culture play especially with today's between each country, each nation increasingly frequent cultural exchanges and cooperation between colleges and universities of university cultural diversity, diversity, and diversity of phenomenon more and more significant. Therefore, under the background of the present age research of socialist core values education of college students has important theoretical and realistic significance.

(1) Research on college students' socialist core values, be helpful for further construction of the socialist core value system, to promote the popularization of Marxism newest theory achievement, the youth. The socialist core value system contains the core values of contemporary university students, the core values of contemporary university students reflects the spiritual essence of the socialist core value system. By studying the core values of college students to further deepen the understanding of socialist core value system, to promote the socialist core value system, to promote the exploration and mining of socialist ideology and social subjects relations, help the cause of socialism with Chinese characteristics and the great cause of national rejuvenation successors.

(2) Research under the multicultural perspective of college students' socialist core values, will be conducive to the value of college students' group consciousness, promote the healthy growth of college students comprehensive [1,2]. Although college students has advantages on levels of knowledge and understanding ability, but not only by their own efforts to form a perfect values. The value evaluation of college students scale more established norms and requirements from society or others, are more easily affected by the outside world multicultural environment. Only strengthen the core values of college students research, wake up to their own reflection and the creation of value and cultural attribute, can fundamentally improve the consciousness of culture and value choice ability, and enhance mental state and space to grow up.

(3) Research under the multicultural perspective of college students' socialist core values, to develop college students' ideological and political education work in the field and space. The impact of the multicultural make people's interests and ideas increasingly diversified, students groups in which the concept is changeable and complex, expanding the field of ideological and political education work. Core values to foster university students is an important component of the socialist core value system, and also is the domain new task of the ideological and political education. Deepening the research on college students' core values to promote the innovation in ideological and political education work of the whole, improve the level of scientific ideological and political education has important significance.

\section{Cultivation Strategy}

Strategy refers to a plan or strategy, is the set can achieve the goal of plan or according to the situation development and course of action. Research under the multicultural perspective of cultivation of undergraduates' values is the key, is to find the corresponding strategy. This will require a change education idea, set up under the multicultural perspective of the basic principles of college students' values education, to guide the specific method of education practice, the innovation education, to explore effective way of college students' values education under the multicultural observes, under the multicultural perspective of college students' socialist core values education truly implemented. Combining previous research results, this paper put forward under the multicultural perspective of college students' socialist core values is shown in figure 1 cultivation strategies [9-11]. 


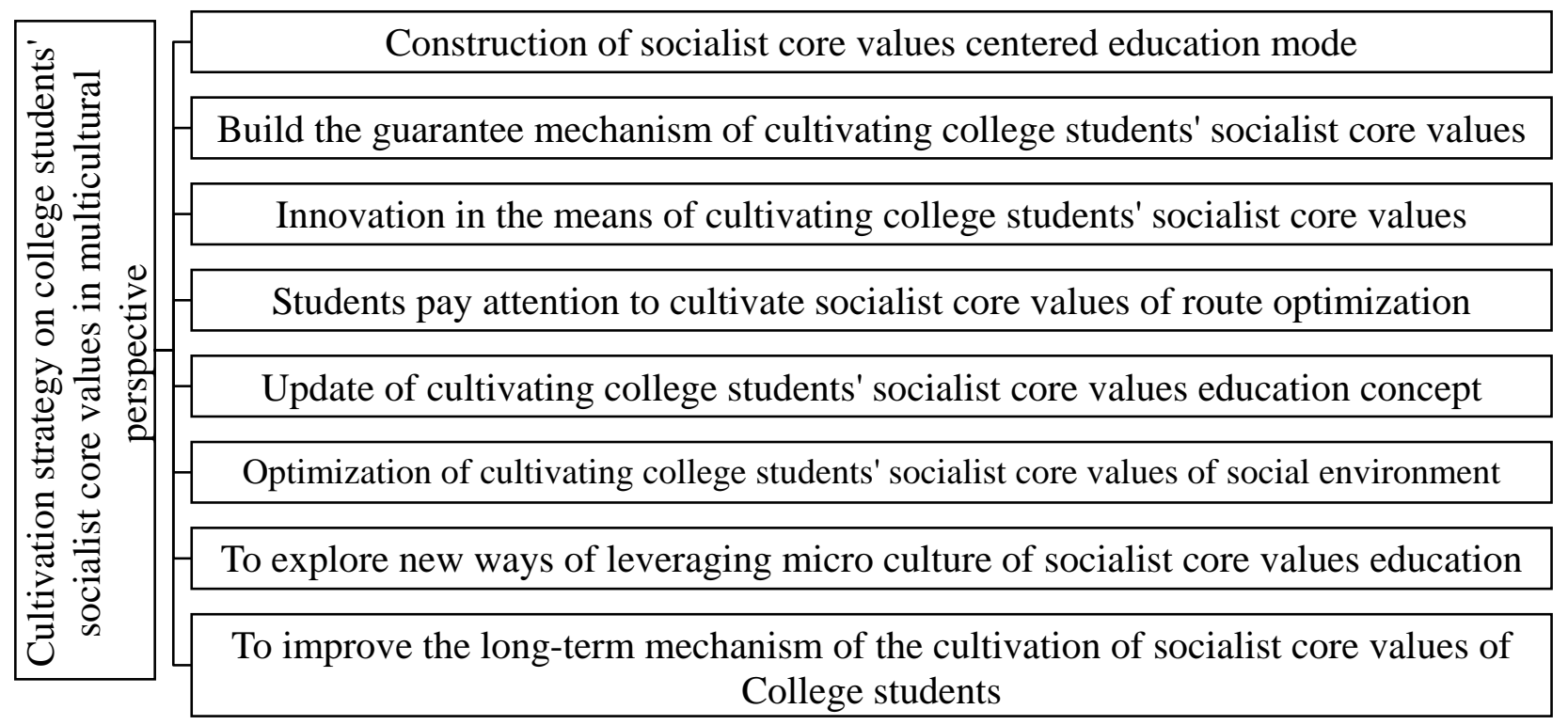

Fig. 1. Cultivation strategy on college students' socialist core values in multicultural perspective

(1) Construction of socialist core values centered education mode. Mainly from the five aspects to build: one is cultural guide, adhere to the guiding ideology of Marxism. Mainstream culture is a society, an era is advocated, the culture plays a main influence. Marxist culture is the mainstream of the contemporary Chinese culture; The second is the social practice, practice in action national spirit with patriotism as the core. On the stage of the social practice gradually formed values, social practice is the sole criterion for testing college students' values is correct; Three is the traditional culture, absorbing essence firmly set up the socialism outlook for honor and dishonor. Concept of honor and disgrace is an important component of the socialist core value system, and embodies the value orientation of socialism, is leading the banner of social fashion; Four is the mass media, promote the position of the mainstream culture. As the emerging media, universal into the information age, the role of the news media increasingly important, only make good use of mass media, can truly play its role to carry forward the mainstream culture; Five is the mechanism construction, ensure the core value system and orderly operation. Along with the socialist core value system is increasingly perfect, need a long-term mechanism to ensure operation. Improve the rules and regulations, perfecting supervision mechanism, especially the role of the good supervision by public opinion.

(2) Build the guarantee mechanism of cultivating college students' socialist core values. Safeguard mechanism from personnel, organization and material in three aspects: personnel security is the premise. Which is included in the contact of cadres, teachers and students in the university, teaching assistant, management personnel and logistics personnel, also including social practice base outside personnel, all kinds of part-time teachers and part-time instructors. Must strengthen the personnel guarantee system, improve the overall quality of workers and university teachers and moral consciousness, especially to build a full-time team of ideological and political theory course teachers and counselors; Security is the core organization. Give up the past rely on ideological and political education theory and the student management department to carry on the education mode, to follow the inherent law of constructing the socialist core values, according to the new change of the social environment and the reform of higher education, following the transition of the college students' way of thinking, to the socialist core values guide the ideological and political education organization reform, rebuild the organizational structure; To ensure the material is the foundation. No certain material base, almost all work harder. Specific measures include increasing capital investment, improve the working environment, strengthen the construction of all kinds of education base. Actively establish all kinds of quality development base, in order to promote college students to build the socialist core values. 
(3) Innovation in the means of cultivating college students' socialist core values. Education should start from life, to students to connect to the real value of the real sex as the breakthrough point, really guide students thinking experience life as the core proposition, based on the real and effective and the core values of the whole. Methods include four aspects: One is that the theory of education to "life". Values education is different from knowledge education, not simply to advance the preset of ethics to infusion, to be based on the students' real life experience; The second is, "education" function of campus culture. Campus culture is the formation of the core values incubator. Through various forms of activities for the carrier of campus culture and positive campus culture atmosphere, formed the core values of health right; Three is that practice of "normal" construction. Give full play to the social practice in the important role in the process of cultivating college students' core values, for college students to provide a variety of practical conditions and opportunity; Four is that self education "self-consciousness". Ignore the value of the subject, simply emphasize external education, it is difficult to obtain actual effect. Core values education educated to fully mobilize the enthusiasm and initiative of its own, self-educated guide education and guidance.

(4) Students pay attention to cultivate socialist core values of route optimization. Help to improve route optimization path connotation, rich path ideas to improve the efficiency path. Existing paths through innovative approaches to enhance the connotation of the times path. Specifically includes three methods: One is, thick and cultivating path of socialist core values of social environment atmosphere, form a social force. Put the mainstream values education in the society as a whole system, expanding the mainstream ideology education of social space, build the path of cultivating social network, for the connection of cultivation content and the full range of college students' life; The second is, add cultivating path of socialist core values into daily life color, return to the students' real life. Return to life is an important modern philosophy paradigm change, but also the inevitable trend in today's world education reform and development. Core values permeate student life, pay attention to nurturing content and effective combination of the way of life, to achieve student subjectivity play directional guidance and nurturing organic unity; Third, improve the socialist core values of nurturing cultural value path, the promotion of cultural consciousness and self-confidence. Cultivate socialist core values and carry forward traditional Chinese culture are inseparable, to enhance the cultural attributes of socialist core values of nurturing, and enhance cultural self-confidence.

(5) Update of cultivating college students' socialist core values education concept. Education concept is the concept of education main body, based on the thinking of education and its, it is a kind of rational knowledge. Core values cultivation should be fully based on the development of students themselves, through the full range and multiple levels approach, in-depth to the educational activities and campus cultural activities, the college students' comprehensive quality improvement to the level of social development requirements, in order to promote the sustainable development of society. Students cultivate socialist core values, not just passively behind economic development, political change and cultural progress, and should be proactive stance in promoting the quality of university students undertake a pilot responsibility optimization practice. Students cultivate socialist core values, should be subject consciousness of citizens, workers sense of ownership, comprehensive development of the self as a breakthrough in the core values of nurturing, thus promoting the concept of university students, psychological, behavioral gradually have to adapt and Modernization good quality, thus truly become qualified successors to the socialist cause. Specific theories include: I love the motherland and love the people, to cultivate qualified citizen; law-abiding dedication, foster qualified workers; Integrity and physical and mental harmony and friendly, nurturing round development of people.

(6) Optimization of cultivating college students' socialist core values of social environment. The current college students' socialist core values cultivation, facing the social environment factors is very complex, mainly for the economic and social transformation of the value of the conflict, the value of the spread of western social thoughts, network public opinion on the value of the university students, the value of the University education. The social environment is an important constraint 
Students cultivate core values. The main optimization from three aspects: First, play the function of public opinion and build a harmonious social and cultural environment. Integration of social resources, and mobilize all sectors of society to participate, to take a variety of forms, opening up a variety of channels, create conditions conducive to the healthy growth of college students a good social and cultural environment; Second, carry forward traditional Chinese culture, to create a good living environment. System reflects the cultural values of the Chinese nation traditional virtue and the perfect combination of spirit, with its profound background and profound philosophic theory, give a person with profound enlightenment and thinking plays an important role in college students' values education; Third, standardized network system to protect the scientifically correct values publicity. In the network environment, human psychology and ideology is illusory sidetracked, in the absence of government standards, will result in a network of unethical behavior.

(7) To explore new ways of leveraging micro culture of socialist core values education. Micro culture as a new cultural form, originated in the popular micro blog popular and mature in micro-channel, wide spread of micro-fiction, micro-film, micro-video, micro-public, the popularity of the Internet, especially closely related to the development of mobile Internet. With its convenient micro culture, popular, dynamic and personalized other unique advantage has become a new cultural form, affecting people's daily lives. College students are the absolute subject of micro-cultural communication and the most active user base. To give full play to the advantages of the micro-culture in the socialist core values education activities, advocacy mainstream ideology, to avoid micro-cultural disadvantages. Leveraging micro culture main measures to develop the socialist core values education as follows: to enhance learning, improve the ideological and political work in the ranks of micro-cultural awareness; Opinion leaders play a positive guiding role, although micro-culture emphasizes fair say, but the actual propagation opinion leaders still have a leading role; With the micro-culture platform, innovative ways to carry out the socialist core values education; Good supervision and management, enhance network security education, to discover information about dynamic groups of students, preventive and treatment work to prevent the spread of illegal information.

(8) To improve the long-term mechanism of the cultivation of socialist core values of College students. University stage is an important period of the formation of value, the value of college students is not mature, lack of stability. Due to lack of life experience, is not firm, the right and wrong idea, has the curiosity of things and new ideas. Therefore, to build a long-term mechanism that can play the core values, to fully play the role of the guidance of the belief, strengthen the ideal of university students, the core values of the ideal and belief, continue to carry out self education and self restraint, establish and improve the long-term mechanism. With organic integration, comprehensive coverage as the basic idea, pay attention to the combination of education guidance, cultural influence and practice, and vigorously promote the cultivation of socialist core values. Gradually realize the cultivation and practice the socialist core values of the institutionalization and normalization. We should cultivate and practice the socialist core values into all aspects of the whole process and higher education; We should cultivate and practice the socialist core values implemented in the school's educational philosophy and governance processes; To carry out a variety of conservation practices socialist core values; Communist and academic elite, to play an exemplary role in nurturing and practice the socialist core values in the process.

\section{Conclusion}

College students are the future of the nation and the hope of the country, is the key to the construction of socialist core value system of the crowd. College students is the core values of socialist core value system in the concentrated reflection on the level of college students' values, in the entire value system of college students at the core and dominant position, standard lead the college students' ideas of daily behavior. Core values research university students is an important component of the socialist core value system of research, is the system of socialist core values, core values, the extension and expansion in the field of higher education. This research with diverse culture theory and the theory of socialist core values as the instruction, from the Angle of education 
management and education workers, solve the problem of cultivating college students' socialist core values of strategy. This study enriched the college students' socialist core values education theory system, for under the multicultural perspective of cultivating college students' socialist core values put forward the feasible strategy, all-round to the core values of college students to nurture and guide, to help college students actively from behind, the influence of the erosion of decadent culture and errors, firmly establish the socialist core values.

\section{Acknowledgement}

This work is supported by social science fund project of Liaoning province (L15BSZ021): Cultivation Strategy on College Students' Socialist Core Values in Multicultural Perspective

\section{References}

[1] W. L. Zheng, "On the value of contemporary college students under the multicultural background," Educational Review, vol. 31, no. 1, pp. 21-23, 2015.

[2] X. C. He, X. Chen, "Research review on college students' socialist core values education under the multicultural background," Education Exploration, vol. 34, no. 3, pp. 30-31, 2014.

[3] Z. Han, "A talk on the construction of a long-term mechanism for the construction of the core values of higher education in Colleges and Universities: Improving ways and means of innovative discourse system," http://www.jyb.cn/high/sjts/201501/t20150122_611280.html, 2015-1-22.

[4] W. J. Liu, "Micro culture: the current culture card," China Youth Daily, 2015-01-05.

[5] X. Wang, L. Ding "On the development trend of Ideological and political education resources in the new period," China Adult Education, vol. 24, no. 18, pp. 64-66, 2015.

[6] Z. Miao, "Innovation research on education of college students' values in multicultural perspective," Master's degree of Shaanxi Normal University, 2013.

[7] Z. Y. Liu, "The Research on Socialist Core Values Mechanism for College Students," Master's degree of South-Central University For Nationalities, 2013.

[8] Y. Jin, H. Z. Chen, "On Social Practice and College Students' Education of Socialist Core Values," Journal of Hebei Normal University for Nationalities, vol. 34, no. 4, pp. 101-104, 2014.

[9] G. Y. Liu, "On Ways to Cultivate Socialist Core Values of Contemporary College Students," Master's degree of Guangxi University, 2014.

[10] X. X. Chi, "The dual task of the socialist core values education is confronted with the dual task of improving the concept and ability," People's Education, vol. 66, no. 10, pp. 24-26, 2015.

[11] Y. P. Liu, "Analysis on the social environment factors that influence the cultivation of the core values of College Students," Education Exploration, vol. 35, no. 9, pp. 117-120, 2015. 